\title{
Struktur Anatomi Daun Mangrove Api-api Putih [Avicennia marina (Forsk.) Vierh] di Pantai Mangunharjo, Semarang
}

\section{Anatomical Structure of White Flames Mangrove Leaves [Avicennia marina (Forsk.) Vierh] on Mangunharjo Beach, Semarang}

\author{
Atia Nadira Lumban Tobing, Sri Darmanti*, Endah Dwi Hastuti, Munifatul Izzati \\ Program Studi Biologi, Fakultas Sains dan Matematika, Universitas Diponegoro, Semarang \\ *Email: darmantisri@yahoo.co.id
}

Diterima 7 Januari 2021 / 28 April 2021

\begin{abstract}
ABSTRAK
Mangrove api-api putih (Avicennia marina) adalah jenis mangrove yang dapat hidup di lingkungan dengan kondisi salinitas, intensitas cahaya, dan suhu dengan kisaran yang cukup luas. Hal tersebut ditunjang oleh kemampuan adaptasi secara fisiologi, anatomi maupun morfologi. Adaptasi anatomi terutama berkaitan dengan kemampuan mengabsorbsi air dan hara dari media tanam dengan potensial osmotik rendah yang disebabkan oleh salinitas tinggi, kemampuan regulasi kandungan garam yang tinggi pada jaringan dan kemampuan menekan laju transpirasi. Penelitian ini bertujuan untuk menganalisis struktur anatomi daun $A$. marina yang tumbuh di Pantai Mangunharjo, Semarang. Sampel adalah daun ketiga dari ujung cabang. Masing-masing sampel diambil pada dua titik sampling, yaitu di tambak dan pantai. Tiap titik sampling diambil tiga pohon mangrove dengan ukuran pohon yang hampir sama. Preparat penampang lintang daun dibuat dengan metode embedding. Hasil penelitian menunjukkan struktur anatomi daun A. marina dari permukaan adaksial ke permukaan abaksial berturut-turut tersusun atas kutikula, epidermis atas, kelenjar garam, jaringan hipodermis, jaringan mesofil yang terdiri atas jaringan palisade parenkim dan spons parenkim. Sebelah bawah dari spons parenkim terdapat epidermis bawah dengan derivatnya berupa trikoma nonglandular dan stomata dengan tipe kriptofor.
\end{abstract}

Kata kunci: adaptasi, anatomi, daun, mangrove, salinitas

\begin{abstract}
Grey mangrove (Avicennia marina) is a type of mangrove that can live in environments with various levels of salinity, light intensity and temperature. This is supported by the ability to adapt physiologically, anatomically, and morphologically. Anatomical adaptations are mainly related to the ability to absorb water and nutrients from planting media with low osmotic potential due to high salinity, the ability to regulate high salt content in tissues and reduce the rate of transpiration. This study aims to analyze the of the anatomical structure of A. marina leaves that grow in Mangunharjo Beach, Semarang. The samples were the third leaf from the tip. Each branch was taken at two sampling points, namely the pond and the coast. At each sampling point, three similar-sized mangrove trees were chosen. Cross-section slides of the leaves were made by using the embedding method.The results showed the anatomical structure of A. marina leaves from the adaxial surface to the abaxial surface consisted of cuticle, upper epidermis, salt glands, hypodermal tissue, mesophyll tissue consisting of palisade parenchyma tissue and sponge parenchyma tissue, respectively.Below the sponge parenchyma tissue is the lower epidermis with its derivatives in the form of nonglandular trichomes and cryptophoric stomata.
\end{abstract}

Keywords : adaptation, anatomy, leaf, mangrove, salinity 


\section{PENDAHULUAN}

Mangrove adalah jenis tumbuhan yang banyak dijumpai di pantai-pantai landai berlumpur dan muara-muara sungai. Ekosistem mangrove memiliki fungsi ekologis dan ekonomis yang sangat bermanfaat bagi organisme di lingkungan pesisir, termasuk manusia. Salah satu peran mangrove adalah melindungi kawasan pesisir dari ancaman erosi, sedimentasi dan rebesan air laut (Zulkarnaini et al. 2017). Pejabat Pengelola Informasi dan Dokumentasi Kementerian Lingkungan Hidup dan Kehutanan (2017) menyatakan bahwa pada tahun 2015 Indonesia memiliki ekosistem mangrove terluas di dunia serta memiliki keanekaragaman hayati yang paling tinggi. Indonesia memiliki panjang garis pantai sepanjang 95,181 $\mathrm{km}^{2}$ dengan luas hutan mangrove 3.489.140,68 ha. Jumlah ini setara dengan $23 \%$ ekosistem mangrove dunia yaitu dari total luas 16.530 .000 ha.

Avicennia marina adalah salah satu spesies mangrove yang paling toleran terhadap garam, yang tersebar luas di sepanjang gradien salinitas dan kekeringan. A. marina terdiri dari tiga subspesies yang terdistribusi pada habitat dengan kondisi iklim yang bervariasi, yaitu: subsp. eucalyptifolia di daerah tropis basah, subsp. marina di daerah tropis kering dan subsp. australasica di daerah beriklim sedang dengan curah hujan menengah (Li et al., 2016). Halidah (2014) mengemukakan bahwa A. marina juga disebut dengan api-api putih, berupa pohon yang tumbuh tegak dengan ketinggian mencapai $30 \mathrm{~m}$. Tumbuhan ini memiliki sistem perakaran horizontal yang rumit dengan bentuk seperti pensil atau seperti asparagus dan akar nafas tegak dengan sejumlah lentisel. Kulit kayu A. marina halus dengan burik hijau-abu, sedangkan ranting muda dan tangkai daun berwarna kuning. Tumbuhan ini merupakan pionir pada lahan pantai yang terlindung, memiliki kemampuan menempati dan tumbuh pada berbagai habitat pasang surut. A. marina sering bergerombol membentuk suatu kelompok pada habitat tertentu.

Avicennia marina memiliki struktur anatomi yang kompleks. Struktur anatomi $A$. marina, seperti mangrove pada umumnya, mempunyai mekanisme adaptasi untuk dapat menyesuaikan diri pada kondisi lingkungan yang ekstrem, sehingga A. marina tetap dapat bertahan hidup. Bagian anatomi daun khusus A. marina meliputi kelenjar pengeluaran garam (saltextruding gland) yang terletak di epidermis serta jaringan penyimpanan air. Banyak jaringan penyimpanan air di jaringan hipodermis yang menunjukkan sifat modifikasi A. marina di habitat dengan salinitas tinggi. Struktur anatomi A. marina menunjukkan karakter xeromorphic seperti kutikula tebal, jaringan penyimpanan air (hipodermis), jaringan palisade yang lebar, kelenjar garam, dan trikoma yang berperan dalam adaptasi anatomi (Surya dan Hari, 2017).

Penelitian secara morfologi telah banyak dilakukan, namun penelitian secara anatomi pada tanaman mangrove sangat jarang dilakukan di Indonesia. Oleh karena itu, perlu dilakukan penelitian mengenai struktur anatomi salah satu spesies mangrove, yaitu mangrove api-api putih (Avicennia marina). Tujuan penelitian ini adalah untuk mengkaji struktur anatomi daun A. marina.

\section{METODE PENELITIAN}

Pengambilan sampel daun A. marina dilakukan pada bulan Juni 2020 di hutan mangrove yang terletak di pantai Mangunharjo, Kelurahan Mangkang Wetan, Kecamatan Tugu, Semarang, Jawa Tengah. Pembuatan dan pengamatan preparat dilakukan di Laboratorium Biologi Dasar dan Laboratorium Struktur dan Fungsi Tumbuhan Departemen Biologi Fakultas Sains dan Matematika, Universitas Diponegoro.

Bahan yang digunakan adalah daun ketiga tanaman A. marina, alkohol, xilol, parafin, gliserin, safranin, dan canada balsam. Alat-alat utama yang digunakan adalah staining jar, rotary microtome dan fotomikrograf. Diambil daun urutan ketiga dari ujung ranting pohon dari 3 pohon yang berbeda, dimasukkan ke dalam kantong plastik, dan diletakkan di ice box. Preparat penampang melintang daun dibuat dengan metode embedding menggunakan parafin (Ruzin, 2000). 


\section{HASIL DAN PEMBAHASAN}

Hasil pengamatan terhadap preparat penampang melintang daun A. marina menunjukkan daun $A$. marina tersusun atas jaringan epidermis atas (adaksial) dan epidermis bawah (abaksial), jaringan dasar (mesofil) yang meliputi jaringan palisade parenkim dan jaringan spons parenkim serta jaringan pengangkut (xilem dan floem) yang tersebar di antara jaringan mesofil (Gambar 1). Bagian penyusun daun Avicennia marina dari permukaan atas ke permukaan abaksial berturut-turut adalah: kutikula, epidermis adaksial, kelenjar garam, jaringan hipodermis, jaringan mesofil yang dibedakan atas palisade parenkim dan parenkim spon, jaringan pengangkut yang terdiri atas xilem dan floem, epidermis bawah, trikoma nonglandular, dan stomata. Trikoma glandular (kelenjar garam), trikoma nonglandular, dan stomata merupakan derivat epidermis atas dan bawah. Stomata daun A. marina memiliki tipe kriptofor. Berkas pengangkut pada ibu tulang daun bertipe kolateral terbuka dan terletak teratur di jaringan mesofil dengan ukuran yang hampir seragam. Surya dan Hari (2017) menyatakan bahwa mangrove memiliki lima lapisan jaringan utama, yaitu epidermis adaksial (epidermis atas), hipodermis, palisade, spons dan epidermis abaksial (epidermis bawah).

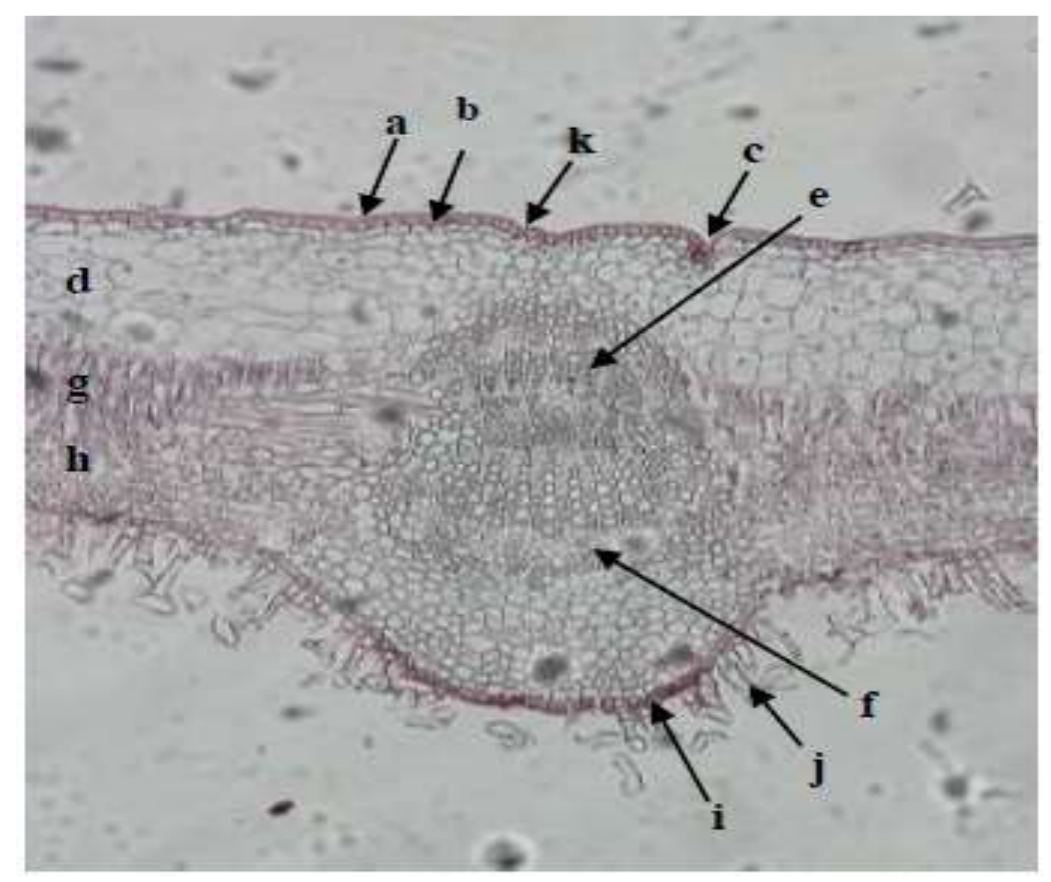

Gambar 1 Penampang melintang daun Avicennia marina. Kutikula (a), epidermis atas (b), kelenjar garam (c), jaringan hipodermis (d), xilem (e), floem (f), jaringan palisade parenkim (g), jaringan spons parenkim (h), epidermis bawah (i), dan trikoma nonglandular (j), stomata (k). Perbesaran 400x.

\section{Kutikula}

Kutikula adalah lapisan terluar daun yang terletak di sebelah luar epidermis. Pada daun $A$. marina, kutikula terdiri dari beberapa lapis. Lapisan kutikula dari permukaan luar ke dalam berturut-turut meliputi lilin epikutikular, kutikula sejati, lapisan kutikula, lapisan pektin, dan dinding sel selulosa. Kutikula adalah lapisan lilin yang tebal dan berfungsi sebagai pelindung untuk membatasi transpirasi berlebihan pada tanaman yang hidup di habitat bersuhu tinggi seperti di pantai. Hal ini merupakan salah satu bentuk adaptasi terhadap cekaman lingkungan. Surya dan Hari (2017) menegaskan bahwa permukaan kutikula biasanya halus, kecuali spesies Avicennia yang terdapat trikoma glandular yang berlimpah. Kehadiran kutikula merupakan ciri adaptif mangrove. 
Kutikula yang tebal pada daun A. marina mengontrol laju transpirasi untuk mempertahankan kadar air. Lapisan kutikula membentuk permukaan daun mengkilap, dapat memantulkan sinar matahari yang berlebihan di permukaan daun sehingga dapat mengurangi transpirasi (Lakna, 2017). Hal ini sesuai dengan pendapat Kim et al. (2017) bahwa kutikula dapat mempengaruhi paparan sinar matahari pada membran tilakoid sehingga dapat mengontrol laju asimilasi karbon. Kutikula yang tebal pada daun mangrove merupakan ciri yang konstan, yang berfungsi untuk mengurangi kehilangan air yang berlebihan.

\section{Epidermis}

Epidermis terdiri atas epidermis atas (adaksial) dan epidermis bawah (abaksial). Epidermis atas adalah lapisan sel yang terletak di bawah kutikula dan di atas jaringan hipodermis, sedangkan epidermis bawah adalah lapisan sel yang terletak di bawah jaringan spons parenkim (Gambar 2). Keduanya hanya tersusun atas 1 lapis sel yang tersusun rapat dan dilapisi oleh kutikula. Hal ini sesuai dengan pernyataan Jacoeb et al. (2011) bahwa helaian daun A. marina memiliki dua lapis jaringan epidermis, yaitu epidermis atas dan epidermis bawah. Jaringan epidermis atas daun A. marina tersusun atas 1 lapis sel tipis yang dilapisi kutikula. Jaringan epidermis bawah tersusun atas 1 lapis sel tipis yang terdiferensiasi membentuk struktur tambahan, yaitu trikoma nonglandular.

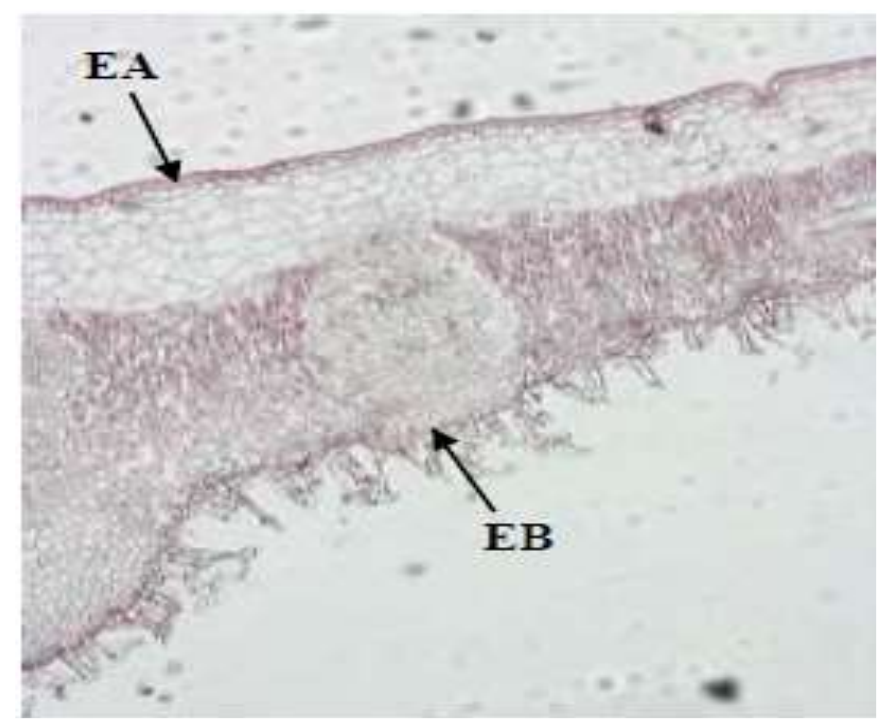

Gambar 2. Epidermis atas (EA) dan epidermis bawah (EB) pada penampang melintang daun Avicennia marina. Perbesaran 100x.

Perbedaan utama antara epidermis atas dan epidermis bawah adalah derivatnya. Derivat epidermis atas berupa trikoma glandular yang merupakan epidermis atas yang mengalami modifikasi menjadi kelenjar multiseluler yang mampu mensekresikan garam. Kelenjar ini berbentuk bulat dan dilapisi oleh kutikula. Derivat epidermis bawah ada dua, yaitu trikoma glandular berupa kelenjar garam seperti pada epidermis atas dan trikoma nonglandular.
Trikoma nonglandular merupakan modifikasi dari epidermis bawah dengan ukuran dan bentuk yang bervariasi, namun trikoma ini tidak mampu mensekresikan garam. Hal ini sesuai dengan pendapat Surya dan Hari (2017) yang menyatakan bahwa trikoma glandular dan nonglandular terdapat pada daun spesies Avicennia.

Epidermis merupakan jaringan pada daun yang berfungsi untuk melindungi jaringan- 
jaringan lain pada daun dari cekaman lingkungan. Epidermis adalah lapisan sel terluar pada tanaman yang memberikan perlindungan fisik terhadap hilangnya kadar air dan kerusakan mekanis pada tanaman. (Crang et al., 2018). Epidermis atas merupakan satu lapisan sel di permukaan atas daun yang membantu proses konservasi air. Umumnya, sel epidermis tidak mengandung klorofil, kecuali pada sel penutup stoma (Lakna, 2017).

\section{Kelenjar garam}

Kelenjar garam merupakan modifikasi dari epidermis. Sejumlah kelenjar garam tersebar sepanjang epidermis atas dan epidermis bawah. Kelenjar garam daun A. marina merupakan kelenjar multiseluler yang berbentuk bulat (Gambar 3). Kelenjar garam terlihat di lubang dangkal pada permukaan atas daun. Setiap kelenjar garam terdiri dari 2-4 sel basal dan ditutupi oleh kutikula tipis. Kelenjar garam bersifat multiseluler dengan 2 sampai 3 sel. Jacoeb et al. (2011) mengemukakan bahwa struktur tambahan yang berada di epidermis adalah kelenjar garam (salt gland). Kelenjar garam merupakan organ yang berasal dari modifikasi sel epidermis yang terjadi sebagai bentuk adaptasi terhadap kelebihan garam pada daun.

Kelenjar garam merupakan alat pengeluaran garam yang berlebihan di dalam tubuh mangrove. Kelenjar garam memiliki peran penting dalam adaptasi anatomi mangrove. Tan $e t$ al. (2013) mengemukakan bahwa kelenjar garam pada mangrove menghilangkan kadar garam yang berlebihan menggunakan pengangkut ion yang akan mengeluarkan garam melalui permukaan daun. Kelenjar garam dapat mengeluarkan garam dalam jumlah besar dengan cara mengekskresikan garam melalui permukaan daun. Selanjutnya garam yang sudah dieksresikan akan terlindi oleh air hujan atau embun.

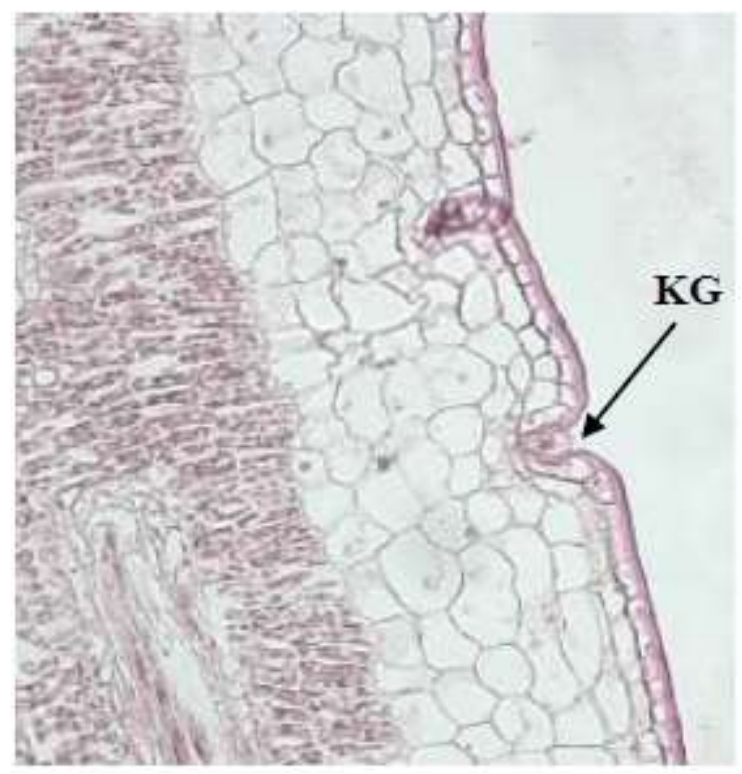

Gambar 3 Kelenjar garam (KG) pada penampang melintang daun Avicennia marina. Perbesaran 1000x.

\section{Jaringan hipodermis}

Jaringan hipodermis merupakan jaringan yang terletak di bawah epidermis atas dan di atas jaringan palisade parenkim. Jaringan hipodermis memiliki sel-sel yang tersusun tidak teratur, padat, dan berukuran lebih besar dibandingkan sel-sel pada jaringan lainnya. Hal ini sesuai dengan penelitian Jacoeb et al. (2011) bahwa hipodermis daun A. marina tersusun atas sel-sel yang lebih besar daripada sel penyusun epidermis. Sel-sel hipodermis berperan sebagai tempat penyimpanan air pada daun atau sebagai sukulensi agar daun tidak mengalami kekeringan di habitat bersuhu tinggi. 


\section{Jaringan mesofil}

Jaringan mesofil daun A. marina tersusun atas jaringan palisade parenkim di bagian atas dan jaringan spons parenkim di bagian bawah. Jaringan pembuluh (vascular bundle) tersebar di antara jaringan mesofil. Surya dan Hari (2017) menyatakan bahwa mesofil memiliki dua bagian yang berbeda, yaitu jaringan palisade yang terletak di bawah epidermis atas dan jaringan spons yang terletak di atas epidermis bawah. Kedua jaringan tersebut memiliki struktur yang berbeda, namun keduanya memiliki peran penting dalam proses fotosintesis.

Jaringan palisade parenkim merupakan salah satu jaringan mesofil pada daun. Jaringan palisade parenkim terletak di bawah jaringan hipodermis dan di atas jaringan spons parenkim. Struktur jaringan palisade parenkim berupa selsel memanjang berukuran kecil dan berjumlah banyak. Sel-sel palisade parenkim tersusun sangat rapat. Jacoeb et al. (2011) menyatakan bahwa jaringan palisade Avicennia marina tersusun secara kompak dan menunjukkan sedikit ruang antar sel. Palisade pada daun A. marina terdiri atas 3 sampai 4 lapis sel yang memanjang vertikal di bawah hipodermis. Daun A. marina bertipe dorsiventral karena daun A. marina hanya memiliki jaringan palisade pada sisi bagian atas daun saja. Jaringan palisade parenkim memiliki peran penting dalam proses fotosintesis karena jaringan ini mengandung banyak kloroplas.

Jaringan spons parenkim merupakan salah satu jaringan mesofil pada daun. Jaringan spons parenkim terletak di bawah jaringan palisade parenkim dan di atas epidermis bawah. Jaringan spons parenkim daun A. marina memiliki sel-sel dengan bentuk yang bervariasi dan tersusun secara acak, beraturan, sangat padat, berukuran kecil, berjumlah banyak, dan sedikit ruang antar sel. Starzecki (2015) mengemukakan bahwa jaringan spons merupakan bagian dari mesofil yang membentuk lapisan di sebelah sel palisade di daun. Jaringan spons parenkim atau bunga karang daun A. marina tersusun atas 2 sampai 3 sel lapis sel di bawah jaringan palisade dan tersusun secara tidak beraturan dan kompak dengan sedikit ruang antar sel (Jacoeb et al.,
2011). Fungsi jaringan spons adalah memungkinkan terjadinya pertukaran gas yang dibutuhkan untuk fotosintesis. Jaringan spons tersusun secara renggang untuk pertukaran gas yang efisien dan terdapat klorofil dalam jumlah sedikit, tidak seperti jaringan palisade parenkim, dan berfungsi sebagai tempat penyimpanan sementara hasil fotosintesis yang berupa gas (oksigen) serta tempat terjadinya fotosintesis. Spons parenkim adalah jaringan asimilasi utama (Surya dan Hari, 2017).

\section{Jaringan pengangkut}

Berkas pengangkut (vascular bundle) pada tulang daun A. marina bertipe kolateral terbuka, yaitu xilem dan floem terletak berdampingan dan dibatasi oleh kambium. Berkas pengangkut tersusun secara berkelompok dan terletak di antara jaringan mesofil (Hilal, 2019). Jacoeb et al. (2011) menyatakan bahwa berkas pengangkut daun A. marina terdiri atas pembuluh xilem pada bagian dalam dan floem pada bagian luar.

Xilem dan floem terletak di bagian tengah pertulangan (midrib) daun A. marina. Sel-sel xilem dan floem tersusun secara berkelompok dan rapat dengan ukuran sel yang bervariasi. Keduanya memiliki peran penting dalam sistem transportasi. Sasomsaptawee et al. (2017) mengemukakan bahwa tipe stele A. marina adalah eustele yang memiliki cincin konsentris dengan berkas pengangkut kolateral.

Floem merupakan jaringan kompleks yang terdiri dari beberapa unsur dengan tipe yang berbeda yaitu buluh tapisan, sel pengiring, parenkim serabut, sklereid. Kadang-kadang ada sel atau jaringan sekretori yang bergabung di dalamnya, misalnya kelenjar getah. Fungsi floem sebagai jaringan translokasi bahan organik (asimilat) yang terutama berisi karbohidrat dalam jumlah kecil ditemukan juga asam amino dan hormon.

Pada dasarnya, xilem merupakan jaringan kompleks karena terdiri dari beberapa tipe sel yang berbeda baik yang hidup maupun yang tidak hidup. Penyusun utamanya adalah trakeid dan trakea sebagai saluran transportasi air, dengan penebalan dinding yang cukup tebal sekaligus 
berfungsi sebagai penguat atau penyokong. Komponen xilem yang lain meliputi serabut sklerenkim sebagai jaringan penguat serta sel-sel parenkim yang hidup dan berfungsi dalam berbagai kegiatan metabolisme. Beberapa spesies yang paling toleran terhadap garam dan spesies yang tahan kekeringan memiliki kambium suksesif, dimana sel floem dan parenkim berada di dekat xilem dan tersusun dalam pita konsentris (Robert et al., 2011).

\section{Trikoma}

Pada daun A. marina, epidermis dijumpai trikoma glandular dan trikoma nonglandular. Epidermis atas hanya terdapat trikoma glandular (kelenjar garam), sedangkan epidermis bawah terdapat trikoma glandular dan nonglandular. Trikoma merupakan derivat epidermis yang memiliki ukuran yang bervariasi dan tersusun tidak teratur. Surya dan Hari (2017) menyatakan bahwa trikoma glandular dan nonglandular terdapat pada daun spesies Avicennia. Trikoma glandular adalah sel-sel epidermis yang mengalami modifikasi menjadi suatu kelenjar multiseluler yang mampu mengekskresikan garam. Kelenjar ini sering disebut sebagaai kelenjar garam.

\section{Stomata}

Stomata adalah derivat epidermis yang terdapat di epidermis atas dan epidermis bawah. Tipe stomat pada A. marina adalah kriptofor, yaitu stomata yang sel-sel penutupnya berada jauh di bawah permukaan daun (tersembunyi). Posisi stomata kriptofor lebih masuk ke dalam daripada epidermis di sekitarnya (Samsuri, 2013).

\section{KESIMPULAN}

Struktur anatomi daun Avicennia marina dari permukaan atas ke bawah berturut-turut tersusun atas kutikula, epidermis atas (adaksial), kelenjar garam, jaringan hipodermis, jaringan mesofil (jaringan palisade parenkim dan jaringan spons parenkm), jaringan pengangkut (vascular bundle), epidermis bawah (abaksial), trikoma glandular, dan stomata. Tipe berkas pengangkut pada ibu tulang daun bertipe kolateral terbuka. Derivat-derivat epidermis berupa trikoma glandular dan stomata tipe kriptofor.

\section{UCAPAN TERIMA KASIH}

Penulis menyampaikan ucapan terima kasih kepada Prof. Dr. Endah Dwi Hastuti, M.Si., Dr. Munifatul Izzati, M.Sc., dan Dr. Sri Darmanti, M.Si. yang telah memberi kesempatan mengikuti penelitian pada kegiatan Riset Pengembangan dan Penerapan sumber dana selain APBN Universitas Diponegoro Tahun Anggaran 2019 No. 329-47/UN7.6.1/PP/2020.

\section{DAFTAR PUSTAKA}

Crang, R., Lyons-Sobaski, S., Wise, R. 2018. Parenchyma, collenchyma, and sclerenchyma. In Plant Anatomy. Springer, Cham, Switzerland, pp 181-213.

Halidah. 2014. Avicennia marina (Forssk.) Vierh Jenis Mangrove Yang Kaya Manfaat. Info Teknis EBONI 11. (1): 37 - 44.

Hilal, F. 2019. A study on morphological and anatomical features of Acanthus ilicifolius L. and Excoecaria agallocha L. selected from Ayiramthengu of Kollam district, Kerala. The Pharma Innovation Journal. 8(6): 507-511.

Jacoeb, A.M., Purwaningsih, S., Rinto. 2011. Anatomi, Komponen Bioaktif dan Aktivitas Antioksidan Mangrove Api-api (Avicennia marina). Jurnal Pengolahan Hasil Perikanan Indonesia. (14): 143-152.

Kim, H., Choi, D., Suh, M. C. 2017. Cuticle ultrastructure, cuticular lipid composition, and gene expression in hypoxia-stressed Arabidopsis stems and leaves. Plant Cell Rep. (36): 815-827.

Lakna. 2017. Difference Between Upper and Lower Epidermis. Molecular Biology \& Biochemistry. ResearchGate.

Li, X., Duke, N.C., Yang, Y., Huang, L., Zhu Y., Zhang, Z., Shi, S. 2016. Re-evaluation of phylogenetic relationships among species of the mangrove genus Avicennia from 
Indo-West Pacific based on multilocus analyses. PLOS ONE. (11): e0164453.

Pejabat Pengelola Informasi dan Dokumentasi Kementerian Lingkungan Hidup dan Kehutanan. 2017. International Conference on Sustainable Mangrove Ecosystem. Jakarta, Indonesia.

Robert, E.M.R., Schmitz, N., Boeren, I. 2011. Successive cambia: a developmental oddity or an adaptive structure? PloS One. (1): e16558.

Ruzin, S.E. 2000. Plant Microtechnique and Microscopy. USA: Oxford University Press.

Samsuri, T. 2013. Pengaruh Berbagai Intensitas Cahaya Terhadap Perubahan Struktur Anatomi Daun Tanaman Gaharu (Gyrinops versteegi (Gilg) Domke). Jurnal Ilmiah Biologi Bioscientist. 11-19.

Sasomsaptawee, M., Kermanee, P., Jintana, V. 2017. Anatomical Character of a Mangrove Species Avicennia marina (Forssk.) Vierh. (ACANTHACEAE). Department of Botany, Faculty of Science, Kasetsart University, Bangkok, Thailand. (55): 235-240.

Starzecki, W. 2015. The roles of the palisade and spongy parenchymas of leaves in photosynthesis. Volume 31.

Surya, S. \& Hari, N. 2017. Leaf anatomical adaptation of some true mangrove species in Kerala. International Journal of Pharmaceutical Science and Research. Vol. 2(3):11-14.

Tan, W.K., Lin, Q., Lim, T.M., Kumar, P., Loh, C.S. 2013. Dynamic secretion changes in the salt glands of the mangrove tree species Avicennia officinalis in response to a changing saline environment. Plant Cell Environ. (36): 1410-1422.

Zulkarnaini, Z. Saam, V. Amrivo, and D. Miswadi. 2017. Community Structure and Economic Evaluation Mangrove Village in Bengkalis District. International Journal of Oceans and Oceanography. ISSN 09732667. 11(1): 63-74. 